\title{
Thriving family businesses in tourism and hospitality: A systematic review and a synthesis of the relevant literature
}

\author{
By Mark Anthony Camilleri ${ }^{1}$ and Marco Valeri ${ }^{2}$
}

Suggested citation: Camilleri, M.A. \& Valeri, M. (2021). Thriving family businesses in tourism and hospitality: A systematic review and a synthesis of the relevant literature. Journal of Family Business Management, https:/www.emerald.com/insight/content/doi/10.1108/JFBM-10-2021-0133

This is a prepublication version.

Purpose: This contribution appraises previous theoretical underpinnings that are focused on family businesses in tourism and hospitality. It discusses about the opportunities and challenges for their development.

Method: A systematic literature review was carried out through peer reviewed publications that were indexed in Scopus and Web of Science. It relied on the PRISMA protocol to evaluate rigorous articles and reviews. A content analysis sheds light on high impact contributions on "family business" and "tourism" or "hospitality", that were published since 2010.

Findings: This bibliographic research captured, analyzed and synthesized the findings from previous contributions to identify the factors that are facilitating the growth prospects, long term sustainability and innovative approaches of family businesses within the tourism and hospitality industry.

Originality: Currently, there are just a few contributions that advance relevant knowledge and understanding on the business development of family firms in tourism and hospitality. This research addresses this academic gap as these entities constitute the life blood of tourist destinations in various contexts.

Keywords: tourism; hospitality; family businesses; enterprises; family enterprises; systematic review.

\footnotetext{
${ }^{1}$ Department of Corporate Communication, University of Malta, Malta. Email: mark.a.camilleri@um.edu.mt

${ }^{2}$ Faculty of Economics, Niccolò Cusano University, Rome, Italy.
} 


\section{Introduction}

Small and medium sized businesses including family enterprises prevail in their contribution to economic growth and competitiveness of tourist destinations (Getz and Carlsen, 2005; Kallmuenzer and Peters, 2018). Very often, they are resilient entities and proactive forces in terms of innovation, employment and productivity. The family business is the oldest and the most common model of a for-profit organization. Essentially, it is a commercial entity that is usually owned, managed and led by multiple generations of a family members who are related by blood, marriage or adoption. The owners of family firms have the ability to influence the vision of their business and to formulate long term goals. They are usually involved in the organization, leadership and management of their company. However, family firms may also be co-owned by individuals who are not part of the family.

The Global Family Business Index defines a family firm as an entity that is controlled by family as its members hold more than $50 \%$ of the voting rights. For a publicly listed firm, a firm is classified as a family business if family members own at least $32 \%$ of the voting rights (OECD, 2021). Thus, the vast majority of businesses throughout the world, ranging from small shops to multinational publicly listed organizations who have hundreds of thousands of employees - can be considered family businesses.

In hospitality and tourism, a large number of small enterprises are run by family members (Peters and Kallmuenzer, 2018; Getz and Carlsen, 2005; Getz and Carlsen, 2000) that are operating in various sectors, ranging from hospitality, leisure, recreation and entertainment, among others. Such enterprises are often described as "economic engines" of tourist destinations (Getz, Carlsen and Morrison, 2004; Veloso et al., 2021) and play a critical role in the interface between communities and tourists (Shaw and Williams, 2013). 
While there is a wide plethora of literature that explores different businesses including family firms and enterprises, we argue that there is still a gap in the extant academic knowledge about family businesses in tourism and hospitality settings (Arcese et al., 2021; Baggio and Valeri, 2020; Esparza Aguilar, 2019; Kallmuenzer, Tajeddini, Gamage, T.C., (...), Rojas, A. and Schallner, 2021; Rachmawati and Suroso, 2020). Globally, the vast majority of tourism and hospitality businesses comprise small and medium sized enterprises (SMEs) (Baggio and Valeri, 2020). These entities are the 'life blood' of tourist destinations as many hotels, bed and breakfasts, AirBnBs, restaurants, and small transportation service providers, etc., are usually run by family members in various contexts.

In this light, this contribution examines relevant theoretical underpinnings and empirical studies that are focused on family businesses in tourism and hospitality. Specifically, its underlying research question is: "What are the factors that facilitate the growth and development of family businesses within the tourism and hospitality industry context? Firstly, it provides a thorough review of the extant literature revolving on tourism and hospitality firms that are owned and managed by families. Secondly, it features the results from a systematic analysis that relied on a PRISMA protocol to evaluate articles and review papers from rigorous, peer-reviewed journals. Thirdly, it synthesizes and interprets their findings. In conclusion, it discusses about the implications of this contribution, identifies its limitations and suggests future research avenues to academia.

\section{The family business legacy}

Several researchers classified different types of family businesses. Very often, they strived in their endeavors to clarify what constitutes a family business. Yet, currently, there is no agreedupon definition of what a family business is. Experts in the field tend to describe the characteristics 
of family businesses and discuss about their organizational culture, ownership, leadership, management involvement, strategic control, governance, et cetera (Valeri, 2021; Valeri and Katsoni, 2021). All of these criteria can be considered as very important elements of family firms, depending on where they are, in terms of their lifecycle. Astrachan and Shanker (2003) provided a broad definition on this concept. They argued that family businesses are controlled by members of the family, who have to make decisions regarding their strategic direction.

They were aware that this definition covered a "gamut of possibilities", ranging from large public companies that are run by descendants of founding family members, to shareholders, board members and low-level employees. In many cases, previous authors contended that firms with the same extent of family involvement were or were not always considering themselves as family businesses, and that their views may change over time. Therefore, there are different definitions for family firms in the academic literature.

Family businesses are business entities that are administered by owner-managers and their relatives. They are different from other companies. Their form of ownership may facilitate their ability to take critical actions quickly and to respond to a changing marketing environment (Mtapuri, Camilleri and Dłużewska, 2021; Peña-Miranda, Guevara-Plaza, Fraiz-Brea \& Camilleri, 2021). Family members may usually have closer ties that enable them to come together and do whatever it takes towards a common purpose, to safeguard their family's health and prosperity. While nonfamily businesses may typically focus on maximizing their financial performance and shareholder value (Camilleri, 2020), family owners are more likely to focus on values like family legacy and reputation.

Many authors argued that a family business involves family members who are exerting their influence or control over the strategic direction of a company. Others discussed about family firm behaviors and shed light on their unique, inseparable, synergistic resources and capabilities 
arising from family involvement and interactions (Chrisman, Chua and Sharma, 2005; Habbershon, Williams and MacMillan, 2003). For example, Seaman et al. (2017) consider the interactions between family, business and friendship networks. Other authors also advance relevant knowledge on this topic (Valeri, 2016; Baggio and Valeri, 2020; Valeri and Baggio, 2020a; 2020b; 2020c; 2021).

Unlike the corporations' executives, family members are usually personally as well as professionally involved in their entrepreneurial activities. In this case, there are no boundaries for them. Their relationships with employees are usually characterized by their values of trust, commitment, empathy and transparency as opposed to those held by larger companies. Hence, family firms may not always necessitate formal structures and bureaucratic systems that are prevalent in non-family entities. Family businesses tend to utilize looser control systems, may not rely on procedural hurdles, formal documentation or transactions. Thus, the informal style of family businesses can offer motivating working environments.

Previous research reported that family owner-managers would typically engage in two-way communications with their employees and may usually forge closer relationships with them. This type of enterprise is conspicuous in small organizations where employees are non-unionized, even though they may be expected to engage in varied roles and could be assigned different duties and responsibilities. Such workplaces will usually have low turn-over rates, and still experience fewer industrial disputes and strikes than other businesses.

Conversely, family firms can be dictatorially run by a coercive owner-manager. As a result, employees and family members may have little or no involvement in the running of their business. A typical tension field that may occur in family businesses happens when there is a conflict of interest between the personal needs of the owner-managers and their business. Hence, the business owners' personal characteristics and attributes may play a key role in the performance of their 
family firm. Relevant studies on this topic often reported mixed findings on the working environment and organizational culture of family businesses. Some authors noted that while employees of nonfamily businesses seem to enjoy superior employment packages, rewards, employment terms and physical working conditions, the quality of the job environment in small businesses is poorer than what you find in their larger counterparts (Russo and Tencati, 2009).

Chrisman et al. (2005) maintained that two firms with the same extent of family involvement may not necessarily be considered as family businesses; if they lack the intention, vision, familiness, and/or behaviors that truly represent the essence of a family business. They went on to suggest that family firms exist because of the reciprocal economic and non-economic value that is cocreated through the combination of family and business systems. On the other hand, there may be problems arising from close kinship, ownership and management transfers, that may ultimately result in inefficiencies, conflicting intentions and behaviors that could limit the ability of family businesses to create or maintain distinctive familiness (Miller, Steier and Le BretonMiller, 2003; Steier, 2001, 2003; Stewart, 2003).

For instance, certain family members may want to exert control over their firm in ways that would nullify the value of existing competences and capabilities. Their behaviors could slow down or prevent the development of their organization. The extent to which a firm may be considered as a family business could be determined by the family members' involvement in influencing the leadership decision in their business (Chrisman et al., 2005; Astrachan, Klein and Smyrnios, 2002). It is important to clearly distinguish the differences between family and nonfamily businesses and to subdivide them into various categories. For example, family businesses can be categorized by their size.

Like other SMEs, small family firms may have limited access to resources including financial capital and human capabilities. The very size of their businesses may create a special 
condition, which is often referred to as 'resource poverty' (O'Cass and Weerawardena, 2009). SMEs and family businesses tend to find themselves in an equity gap, where it is very difficult to acquire finance to operate efficiently (Camilleri, 2018). Although banks are key providers of finance through the provision of loans, the availability of unsecured bank finance to these businesses is usually very limited.

The growth of small family enterprises remains severely restricted, particularly if they cannot provide additional securities or collaterals for their investments. Even small businesses with high growth potential may experience difficulties in raising relatively modest amounts of risk capital. Moreover, external forces and potential threats from the marketing environment could have more devastating effects on family businesses than on other companies. For instance, changes in government regulations, tax laws, labor legislation and interest rates may usually affect a greater percentage of expenses in smaller family businesses than they do for other organizations (Brune, Thomsen and Watrin, 2019).

Family-owned businesses may evolve over time as their ownership may be transferred from founder-members to their relatives (Peters, Raich, Märk and Pichler, 2012). Various forms of succession may result in different ownership structures, revised duties and responsibilities of employees of family businesses. The descendants of unrelated founders can find themselves owning and managing their company and may even sit in the same board. In this case, there will be two or more families who have a stake in the business. However, just one of them will be in control (i.e. the largest shareholder) (Astrachan et al., 2002).

For instance, Hoshi Ryokan, Komatsu is one of the oldest hotels in the world. This property has been owned and managed by the Hoshi family in the past centuries. Other popular family businesses in the hospitality sector include Gmachl in Salzburg and Hotel Sacher in Vienna (Austria); Peninsula Hotel in Hong Kong (China); Bristol Hotel in Paris (France); Villa D'Este in 
Como, Italy; Hoshi Ryokan Komatsu in Ishikawa (Japan); Baur-au-Lac in Zurich, Switzerland; Goring Hotel in London, West Lodge Park in Hadley Wood, Hertfordshire (UK) and Seaside hotel Kennebunk in Maine (USA), among others.

\section{Methodology}

This research adopted PRISMA's robust protocol (Moher, Shamseer, Clarke, Ghersi, Liberati, Petticrew ... and Stewart, 2015) to systematically extract and evaluate the content of highimpact academic contributions that that were indexed in Scopus and Web of Science. Hence, this review was carefully planned and documented in all stages, to ensure the accountability, integrity, and transparency of the findings. The search query considered the total number of articles that were published in English through rigorous journals. It also provided details on the number of publications that were published each year. Scopus as well as Web of Science featured a list of contributing authors, identified their papers' subject areas and keywords. Moreover, it sorted them from highest to lowest. These two repositories clearly distinguished between different publication stages, document types and source titles. Table 1 clarifies the methodology that was used to capture, analyze and synthesize the findings from this contribution's systematic review. 
Table 1: The systematic review

Formulation of the research question<smiles>C1CC2CCC1C2</smiles>

PRISMA protocol for systematic analysis

Relevant keywords were inserted in the search query of two databases (i.e. Scopus and Web of Science).

Only contributions that were published in rigorous, peerreviewed journals were identified and screened in this review. Duplicates (that were featured in both databases) were removed.

The query yielded a list of the top journals, related subject areas of contributions, and reported the most popular keywords that were inserted by the authors.

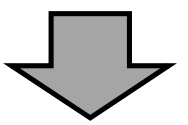

\section{Syntheses and interpretation of the findings from eligible contributions.}

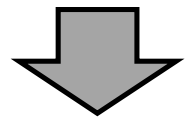

Conclusions and implications

The systematic review considered publications that featured "family business" AND "tourism" OR "hospitality" in their title, abstract and keywords, as of October 2021. The search query excluded books, book series, conference proceedings and trade publications from this review exercise - as they were not considered as rigorous as academic journals. The results revealed that there were 108 contributions in Scopus and 35 in Web of Science. Since 2010, there 68 that were indexed in Scopus and 32 in Web of Science (17 were featured in Social Sciences Citation Index, 11 in Emerging Sources Citation Index and 4 in SCI-EXPANDED). Table 2 presents a list of 43 articles that were focused on family businesses in tourism. It endorses the contributing authors, 
describes their methodological approaches, features the keywords of their research and clarifies their research questions. The following contributions were published since 2010 (to date): 
Table 2 A non-exhaustive list of articles on family businesses in the tourism and hospitality industry context (sorted from highest to lowest citations)

\begin{tabular}{|c|c|c|c|c|c|c|c|c|}
\hline Scopus & WOS & Authors & Year & Source & $\begin{array}{l}\text { Open- } \\
\text { Access }\end{array}$ & Method & Keywords & Research Question \\
\hline 1 & $\begin{array}{l}\text { SSCI } \\
\text { SCI- } \\
\text { Expa- } \\
\text { nded }\end{array}$ & $\begin{array}{l}\text { Vrontis, D., Bresciani, } \\
\text { S., Giacosa, E. }\end{array}$ & 2016 & $\begin{array}{l}\text { British Food } \\
\text { Journal }\end{array}$ & No & Case study & $\begin{array}{l}\text { Cultural identity; Identity; } \\
\text { Family businesses; Innovation; } \\
\text { Territory; Tradition; Wine } \\
\text { sector. }\end{array}$ & $\begin{array}{l}\text { This research analyzed how a strategy based on the } \\
\text { combination of tradition and innovation can offer a } \\
\text { competitive advantage to a medium- } \\
\text { sized family firms operating in the wine sector. }\end{array}$ \\
\hline 2 & SSCI & $\begin{array}{l}\text { Peters, M., } \\
\text { Kallmuenzer, A. }\end{array}$ & 2018 & $\begin{array}{l}\text { Current Issues in } \\
\text { Tourism }\end{array}$ & No & $\begin{array}{l}\text { Qualitative } \\
\text { (Interviews) }\end{array}$ & $\begin{array}{l}\text { Entrepreneurial behavior; } \\
\text { Entrepreneurial orientation; } \\
\text { Family business; Hospitality; } \\
\text { Qualitative. }\end{array}$ & $\begin{array}{l}\text { This explorative study analyzed the owner- } \\
\text { managers' perceptions of entrepreneurial behaviors } \\
\text { (of hospitality enterprises) and their effect on } \\
\text { performance. }\end{array}$ \\
\hline 3 & SSCI & $\begin{array}{l}\text { Hallak, R., Assaker, } \\
\text { G., O’Connor, P. }\end{array}$ & 2014 & $\begin{array}{l}\text { Journal of } \\
\text { Hospitality and } \\
\text { Tourism } \\
\text { Research }\end{array}$ & No & Quantitative & $\begin{array}{l}\text { Business performance; } \\
\text { Entrepreneurial self-efficacy; } \\
\text { Family business; Multigroup } \\
\text { invariance; Small and medium } \\
\text { tourism enterprises; SMTEs; } \\
\text { Structural equation modeling. }\end{array}$ & $\begin{array}{l}\text { This research examined the relationship between } \\
\text { entrepreneurial self-efficacy (ESE) and enterprise } \\
\text { performance in family-owned and nonfamily-owned } \\
\text { small- and medium-sized enterprises. }\end{array}$ \\
\hline 4 & SSCI & Ahmad, S.Z. & 2015 & $\begin{array}{l}\text { Current Issues in } \\
\text { Tourism }\end{array}$ & No & $\begin{array}{l}\text { Mixed } \\
\text { methods }\end{array}$ & $\begin{array}{l}\text { Hotel industry; Motivation; } \\
\text { Problems and challenges; } \\
\text { Small- and medium-sized } \\
\text { hotel; United Arab Emirates } \\
\text { (UAE). }\end{array}$ & $\begin{array}{l}\text { This study explored the determinants and } \\
\text { characteristics of owner-managers of small- and } \\
\text { medium-sized hotels (SMSHs) and identify various } \\
\text { challenges in starting up and operating businesses. }\end{array}$ \\
\hline 5 & SSCI & $\begin{array}{l}\text { Kallmuenzer, A., } \\
\text { Nikolakis, W., Peters, } \\
\text { M., Zanon, J. }\end{array}$ & 2018 & $\begin{array}{l}\text { Journal of } \\
\text { Sustainable } \\
\text { Tourism }\end{array}$ & No & $\begin{array}{l}\text { Qualitative } \\
\text { (Interviews) }\end{array}$ & $\begin{array}{l}\text { Austria; Family business; } \\
\text { Random utility theory; Rural } \\
\text { tourism; Socio-emotional } \\
\text { wealth (SEW); Sustainability. }\end{array}$ & $\begin{array}{l}\text { This study was built on the foundations of socio- } \\
\text { emotional wealth (SEW) and random utility theory, } \\
\text { to understand the drivers of sustainability in } \\
\text { rural tourism family firms (RTFFs). }\end{array}$ \\
\hline 6 & SSCI & $\begin{array}{l}\text { Kallmuenzer, A., } \\
\text { Peters, M. }\end{array}$ & 2018 & $\begin{array}{l}\text { International } \\
\text { Journal of } \\
\text { Hospitality } \\
\text { Management }\end{array}$ & No & Quantitative & $\begin{array}{l}\text { Control mechanisms; Family } \\
\text { business; Hospitality; } \\
\text { Innovativeness; Quantitative; } \\
\text { Social embeddedness; } \\
\text { Tourism. }\end{array}$ & $\begin{array}{l}\text { This study explored the innovativeness } \\
\text { of tourism/hospitality family firms (THFF) and } \\
\text { determined its effect on financial performance. It } \\
\text { also compares it to that in non-tourism/hospitality } \\
\text { industries (non-THFF). }\end{array}$ \\
\hline
\end{tabular}


Expa-

nded

SSCI

Kallmuenzer, A.
2017

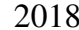

\section{British Food}

Journal

Internationa

Journal of

Contemporary

Hospitality

Management

Journal of Family Business

Management

Journal of Travel No

and Tourism

Marketing

\section{No Case study}

Case study

Qualitative

(Text

analysis)

International

Journal of

Tourism, and

Hospitality

Research

Journal of Brand Management

Sustainability

(Switzerland)

\section{Yes}

Conceptua

Review/

Case study

\section{Review/}

Content

Analysis

Qualitative

Focus

Groups)
Cultural identity; Family businesses; Food sector;

Innovation; Territory;

Tradition

Collaboration; Family

business; Hospitality;

Innovation; Qualitative.

Family business; Innovation; Service experiences; Small businesses.

Business growth; Corporate branding; Familiness; Family values; Sustainable practices.

Case studies; Family business; Family dynamics; Innovation drivers; Sustainability performance; Sustainability practices.

Family business; Network analysis; Network science;

Quantitative methods; Sustainable tourism performance.

\section{Consumer behavior; \\ Familiness; Family business; Tourism.}

The paper clarified how a medium-sized company operating in the food sector should strengthen its business model (through a combination of tradition and innovative approaches).

This research explores which actors in the hospitality industry drive innovation in hospitality family firms and particularly aims at understanding how these drivers contribute to create and sustain competitive advantage.

This paper explored innovation and service experiences in family firms within the tourism industry.

This research explored how family businesses can create and develop a corporate brand in the tourism industry context.

This research identified innovation and sustainability drivers within family businesses in tourism.

This research explored the effects of network structures on the sustainable performance of tourism family businesses.

This research explored the consumers' perceptions on family businesses in tourism. 
Journal of

Hospitality and

Tourism

Management

Lee, Y.-S., Shin, W.-J. 2015

Service Business

SSCI

W.B.

$2012 \quad \begin{aligned} & \text { Asia Pacific } \\ & \text { Journal of } \\ & \text { Tourism } \\ & \text { Research }\end{aligned}$

Research

\section{European}

Camisón, C., Forés

B., Puig-Denia, A.

Peters, M., Raich, M., 2012

Märk, S., Pichler, S.

Management and

Business

Economics

$\begin{array}{cl}\text { No } & \text { Review } \\ \text { No } & \begin{array}{l}\text { Qualitative } \\ \text { (Interviews) }\end{array} \\ & \text { Yes } \quad \begin{array}{l}\text { Qualitative } \\ \text { (Case study) }\end{array}\end{array}$

Family business; Family

dynamics; Family

entrepreneurship; Innovation

drivers; Tourism and

hospitality management.

Oral history; Tourism; Turkey;

Women employees.

Customer experience in

tourism; Master culture and tradition; Storytelling; The sake industry.

Family business; Market sized accommodation; Start-up

Economic profitability; Family

Tourism Review Yes opportunities; Push and pull factors; Small and medium

business; Small and mediumfactors. business; Financial profitability; Tourism sector.

Qualitative

(Inter

Qualitative (Interviews)
Family business; Family firms; GABEK®; Hospitality services; Hotels; Interviews Italy; Qualitative method;

Succession
This paper explored the "family business model" and their innovations in tourism.

This study sheds light on the achievements of female entrepreneurs in the Turkish tourism sector.

This study examines storytelling as a marketing strategy to revitalize the tradition-bound Japanese sake industry.

This article identifies start-up factors for small and medium-sized accommodation (SMSA) businesses

This research evaluates the return on capital in terms of economic and financial profitability of family businesses operating within the tourism sector.

This research sheds light on the different dimension of commitment relevant for the succession process. 
SSCI

$\mathrm{A} \& \mathrm{H}$

CI

SSCI

\section{Ismail, H.N., Mohd Puzi, M.A., Banki, \\ M.B., Yusoff, N.}

2019

Journal of

Tourism and

Cultural Change

No

Family business; Resiliency;

Sustainable tourism;

Transgeneration enterprise.

Hallak, R., Assaker, G. $2013 \quad$ Asia Pacific

Journal of

Tourism

Engeset, A.B.

2020

Esparza Aguilar, J.L.

2019

Family Business

SCIE
Walton, J.K.

Vrontis, D., Culasso,

F., Giacosa, E.

Stupino, M.
2014

Business History

2019

British Food

Journal
Research

Scandinavian

Journal of

Hospitality and

Tourism

Journal of

Management

No

\section{businesses; Multigroup \\ invariance; Small and medium \\ tourism enterprises; South}

Commitment to stay; Family

Australia.

Qualitative

(Interviews)

Sustainability

(Switzerland)

Qualitative

(Interviews)

No

Quantitative

Mexico; MSMEs; Quintana
Roo.

Roo.

Family business; Health;

Leisure; Paternalism; Regional

identity; Spain; Sustainability; Tourism.

Entrepreneurship; Exploration and exploitation activities;

Family businesses; Food

sector.
This paper sheds light on two successful case studies of two tourism SMEs in the islands in Malaysia.

This study examines differences between familyowned and non-family-owned small and

medium tourism enterprises (SMTEs) operating in regional tourism destinations.

This research explores how family businesses respond to various challenges. It reveals how family ownership has influenced the survival of rural hotels.

This research examined family-business owners' perceptions of risks in Austrian tourism destinations.

This paper identifies the CSR practices that were adopted by a Mexican family business and by nonfamily enterprises.

This case study sheds light on a family-run spa hotel with an elite clientele in Galicia, Spain.

This paper focuses on the relevance of adopting an ambidextrous entrepreneurial strategy in the food sector that is characterized by established traditions and changing consumption patterns. 
SSCI $\mid$ Yazici, S., Köseoglu, M.A., Okumus, F.

hmad, S.Z.

Muhammad Arif,

A.M.

Bujan, I.

Prevolsek, B

Rozman, C., Pazek,

K., Maksimovic, A.,

Potocniktopler, J.
2016

Journal of

Organizational

Change

Management

2016

International

Journal of

Hospitality and

Tourism

Administration

2012 Asia Pacific

Journal of

Tourism

Research

Research-

Ekonomska

Istrazivanja

Podravina

No

Quantitative

$\begin{array}{ll}2011 & \text { Tourism } \\ & \text { Recreation } \\ & \text { Research }\end{array}$

research

methods.

Quantitative

Yes

Quantitative
Entrepreneurship; Growth;

Hotels; Island.

\section{Business challenges;}

Entrepreneurship; Hospitality and tourism; Motivation;

Small and medium-sized hotel business; United Arab Emirates.

Quantitative Business challenges;

Entrepreneurship; Hospitality and tourism; Motivation; Small and medium-sized hotel business; United Arab

\section{Emirates.}

Entrepreneurial knowledge; Entrepreneurial orientation;

Non-financial performance; Small family hotels; Socioemotional wealth (S.E.W.)

Family business, Succession, Tourism, Multi criteria, DEX, AHP. AHP.
This research explored farm-owners' motivations to

This research investigates what factors drive growth for independent hotel firms on an island.

This research investigated the determinants and medium-sized hotels (SMSHs) who started up and operated businesses in the United Arab Emirates.

This research explored the marketing aspects of small and medium-sized budget hotels (SMBHs) in three urban cities in East Peninsular Malaysia.

This study identified and measured specific entrepreneurial attributes, knowledge and socioemotional wealth (S.E.W.) of owners of small family hotels.

This study explored the criteria affecting the successful succession of the business transfer in the context of family businesses in tourism.

diversify into tourism accommodation services. characteristics of the owner-managers of small- and 
SSCI | López-Chávez, B.A., Maldonado-Alcudia,

C., Larrañaga Núñez,

A.M.

34

Canovi, M., Lyon, A.

Heimerl, P., Peters, M.

Aguilar, J.L.E., de Lema, D.G.P.
Costanzo, L.A.

Karatas-Özkan, M.

2021

Academia

Latinoamericana

de

Administracion

2020

Tourism

Planning and

Development

2019

Tourism

International

Journal of

Hospitality and

Tourism

Administration

Problems and

Perspectives in

Management

(

2011 Cuadernos de

Administracion

2020

Management

$\begin{array}{ll}\text { No } \quad \text { Review } \quad \text { Article review; } \\ & \text { Competitiveness; Family } \\ & \text { business; Innovation; Strategic } \\ & \text { planning; Tourism. }\end{array}$

\section{Yes Qualitative}

No

Yes

\section{Review}

Journal of Small
Business
(Interviews)

Qualitative

(Focus

Groups)

Qualitative

(Interviews)

\section{hospitality; New Zealand; \\ restaurants; strategy.}

Review

Case Study

Agritourism; Diversification;

Family business; Socio-

emotional wealth; Wine

tourism.

Destination planning; Action research; World café; Family

business; Scenario technique.

\section{Development:}

Entrepreneurship; Growth;

Life cycle; Tourism and

hospitality.

Culture; Family business;

Strategic management;

Tourism sector

Qualitative Family business; qualitative;

(Interviews) Sustainable entrepreneurship.
This study analyzed the current state of knowledge about family businesses in tourism through a

systematic review of international academic literature (the researchers focused on Latin America).

This paper examined the owner-managers' motivations to diversify family wineries' into agritourism service providers.

This research explored the tourism "product", the variety of stakeholders and growing market-pressure forces that can have an effect on small- and mediumsized family businesses in Alpine destinations

This exploratory study therefore examines the communication of strategies in family-owned restaurants to determine the likely impact of family ownership on strategy communication.

This paper examines various factors influencing the performance and success of small tourism and hospitality businesses that operate in West Virginia.

This article studies the culture of four family businesses, and analyses their influence on their strategic management

This study explores the stakeholders' perceptions of sustainable entrepreneurship dimensions in a developing economy. 


\begin{tabular}{|c|c|c|c|c|c|c|c|}
\hline 40 & ESCI & $\begin{array}{l}\text { Rachmawati, E., } \\
\text { Suliyanto, Suroso, A. }\end{array}$ & 2020 & $\begin{array}{l}\text { Journal of } \\
\text { Family Business } \\
\text { Management }\end{array}$ & No & Quantitative & $\begin{array}{l}\text { Entrepreneurial orientation; } \\
\text { Family business performance; } \\
\text { Family involvement; Gender. }\end{array}$ \\
\hline 41 & N/A & $\begin{array}{l}\text { Fyfe, J., Bent, R., } \\
\text { Seaman, C. }\end{array}$ & 2020 & $\begin{array}{l}\text { International } \\
\text { Journal of } \\
\text { Business and } \\
\text { Globalisation }\end{array}$ & Yes & $\begin{array}{l}\text { Qualitative } \\
\text { (Interviews) }\end{array}$ & $\begin{array}{l}\text { Family business; Hotels; } \\
\text { Internet use; Marketing; } \\
\text { Scotland.; Small business; } \\
\text { Tourism }\end{array}$ \\
\hline 42 & ESCI & Giousmpasoglou, C. & 2019 & $\begin{array}{l}\text { Hospitality and } \\
\text { Society }\end{array}$ & Yes & $\begin{array}{l}\text { Qualitative } \\
\text { (Interviews) }\end{array}$ & $\begin{array}{l}\text { General managers; Greece; } \\
\text { Hospitality; Managerial work; } \\
\text { Small and medium luxury } \\
\text { hotels; Work context. }\end{array}$ \\
\hline 43 & ESCI & Tomasella, B., Ali, A. & 2019 & $\begin{array}{l}\text { Hospitality and } \\
\text { Society }\end{array}$ & Yes & $\begin{array}{l}\text { Qualitative } \\
\text { (Interviews) }\end{array}$ & $\begin{array}{l}\text { Corporate social } \\
\text { responsibility; } \\
\text { Entrepreneurship; Foodservice } \\
\text { sector; Hospitableness; } \\
\text { Hospitality industry; Small } \\
\text { business social responsibility; } \\
\text { SMEs }\end{array}$ \\
\hline
\end{tabular}

This study explored the direct effect of entrepreneurial orientation on family business

performance. It also investigated the role of family involvement as a mediating variable and the role of gender as a moderating variable in the relationship between entrepreneurial orientation and family business performance.

This exploratory study is designed to initiate dialogue and to explore the operating environment and perceived business support needs in the evermore complex and dynamic e-environment.

This study explores the mediating factors that affect the general managers' work in small and medium luxury hotels (SMLHs) in a popular tourist destination in Greece.

This article investigates the relationship between personal values, hospitableness and social

responsibility in small, independent foodservice businesses.

SMEs

Note: Sorted from highest to lowest number of citations (in October 2021). 
According to Scopus, the top 10 subject areas of these articles were related to Business, Management and Accounting (45), Social Sciences (26), Economics, Econometrics and Finance (14), Environmental Science (9), Energy (5), Agricultural and Biological Sciences (4), Arts and Humanities (3), Decision Sciences (2), Earth and Planetary Sciences (1), and Engineering (1). Web of Sciences categorized the search results according to the following subject areas: Hospitality, Leisure, Sport and Tourism (11), Management (7), Agricultural Economics Policy (2), Business (2), Economics (2), Food Science Technology (2), Environmental Sciences (1), Environmental Studies (1), Green Sustainable Science Technology (1), Sociology (1) and Transport (1).

Scopus reported that the Journal of Family Business Management (5) was the top journal that published most papers on the topics related to family business in tourism. It was closely followed by Sustainability Switzerland (4), Asia Pacific Journal of Tourism Research (3), British Food Journal (3), Current Issues in Tourism (2), Academia Revista Latino Americana de Administracion (1), Administrative Sciences (1), Asian Academy of Management Journal (1), Business History (1), and Cuadernos de Administracion (1). Web of Science reported the following results: Journal of Family Business Management (3), Asia Pacific Journal of Tourism Research (2), British Food Journal (2), Current Issues in Tourism (2), Sustainability (2), Academia Revista Latinoamericana de Administracion (1), Economic Research Ekonomska (1), Ekonomski Pregled (1), European Journal of Management (1), International Journal of Contemporary Hospitality Management (1), and International Journal of Hospitality Management (1).

The most used keywords in Scopus-indexed publications included: Family Business (30), Tourism (18), Business Development (8), Sustainability (7), Innovation (6), Tourism Development (6), Hospitality (5), Service Sector (5), Small and Medium-sized Enterprise (5), and 
Entrepreneurship (4). The results in Web of Science do not reveal the authors' keywords that were included in their publications. Interestingly, business development (Chan and Quah, 2012; Elmo et al., 2020; Fonseca and Carnicelli, 2021; Peters and Kallmuenzer, 2018; Pikkemaat and Zehrer, 2016; Prevolsek et al., 2017; Walton, 2014;) was featured as the fourth most popular keyword, after "family business", "tourism" and "hospitality".

\section{The development of family firms in tourism and hospitality}

Tourism and hospitality family businesses are characterized by their specific ownership, leadership and organization as well as by their stakeholder relationships, that differentiate them from nonfamily companies (Engeset, 2020; Martínez, Stöhr and Quiroga, 2007; Rosalin et al., 2016; Kumar et al., 2021). Notwithstanding, there are various variables that could enable or disable family firms of different types and sizes, to generate and sustain new business development in the long term (Peters and Kallmuenzer, 2018).

The owners of tourism family firms may try to balance their business objectives with those of their family's interests (Getz and Carlsen, 2005). Other research indicated that the objectives of such family businesses are different than nonfamily-run companies. The former businesses are usually influenced by family issues and lifestyle objectives. While Getz and Carlsen (2000) found that the majority of businesses considered family goals as more important than their business goals; Andersson, Carlsen and Getz (2002) argued that tourism family businesses ought to operate in a profitable manner, if they want to support their family members, and to maintain a decent quality of life. Their thriving businesses could enable them to create a family legacy and to pass on their company to the next generation (Andersson et al., 2002). Again, this cannot be achieved unless it 
is financially successful (Erdogan, Rondi, De Massis, 2020; Williams, Pieper, Kellermanns \& Astrachan, 2018).

Small family-run businesses may be expected to provide employment opportunities to family members. Hence, they are not always recruiting the most qualified employees for the job. This may result in conflicts among employees (Miller et al., 2003; Peters and Buhalis, 2004). Conversely, multinational corporations are capable of attracting the best candidates for the job. They are usually in a better position to lure investors as well as venture capitalists' funds. On the other hand, family business owners may be reluctant to accept financial injections from external investors, for fear of losing control over their business. The personal qualities, traits and attributes of the business owners can have significant effects on the long-term prospects of the companies they lead and manage (Hallak, Assaker and Connor, 2014).

Family firms are not always in a position to raise their margins and to allocate financial resources for research and development and toward market research, product development, skills or creativity enhancement (Pikkemaat and Zehrer 2016). Very often, they are not benefiting from economies of scale that are afforded by bigger businesses. Moreover, they may be reluctant to cooperate and forge alliances with other businesses, including with competitors to gain economies of scope, that could enable them to improve their services. Many academic researchers argued that family firms ought to value long-term cooperation and social networking within the communities where they operate their business (Pikkemaat and Zehrer 2016; Camisón et al., 2016). Their networking (Baggio and Valeri, 2020) and innovation management processes (Kallmuenzer, 2018; Vrontis et al., 2016) are often driven by local community needs and by their orientations towards sustainable tourism development (Baggio and Valeri, 2020; Camilleri, 2014; Ismail et al., 2019; Kallmuenzer et al., 2018). 
Family members may not possess the networking skills to develop fruitful relationships with corporate stakeholders (Arcese et al., 2020; Camilleri, 2016; Troise \& Camilleri, 2021) and/or may lack adequate knowledge to formulate appropriate business strategies for their company (Pikkemaat and Zehrer, 2016). Their businesses are expected to continuously innovate to guarantee their survival and to improve their performance in the long term (Elmo et al., 2020). In a similar vein, Rachmawati et al., (2020) pointed out that family entrepreneurs need to be more innovative and take risks so that they can compete in the global scenario. They suggested that their internationalization prospects may help their business to improve their reputation in order to enhance their bottom lines, whilst satisfying their families' interests. Other authors contended that they have to identify innovation opportunities (Arcese et al., 2020; Giacosa et al., 2017; LópezChávez et al., 2021; Valeri et al., 2020) whilst defending their values and traditions in order to guarantee that their family business legacy transcends from one generation to the next (Obermayer et al., 2021; Santos et al., 2021c).

Succession issues may affect the form of ownership structures of tourism family enterprises as well as their governance, leadership, management and strategies. Elmo et al. (2020) maintained that the innovation process is likely to occur after succession periods when there are changes in the ownership of family businesses. They went on to suggest that successors (i.e. incoming ownermanagers) of family firms may represent new opportunities, resources, and sources of knowledge and information for them. Other authors delved into family succession matters (Kallmuenzer et al., 2021; Ollenburg and Buckley, 2011; Prevolsek et al., 2017; Steier, 2001). In the main, these commentators recognized that succession remains a contentious issue that may either result in positive outcomes or in negative repercussions that can ultimately hinder the growth and development of family businesses (Miller, 2003; Peters et al., 2012). 


\section{Conclusions}

This systematic review confirmed that lately there is a growing interest among academia on research that is focused on small businesses in tourism and hospitality (e.g. Arcese et al., 2020; Baggio and Valeri, 2020; Peters and Kallmuenzer, 2018; Vrontis et al., 2016). It clarified that there are a number of internal and external factors that can affect their long-term prospects (Camilleri, 2017; Camilleri, 2021a; Giousmpasoglou, 2019; Zapalska and Brozik, 2013; Santos et al., 2021a; 2021b). Moreover, it reported that more authors are increasingly investigating their business development, sustainable development and innovation capabilities (Mtapuri et al., 2021, PeñaMiranda et al., 2021). It suggests that family firms differentiate themselves from nonfamily businesses as they consider other important values in addition to profit, including family legacy, trust, commitment and reputation. It explained that it is in their interest to engage with different stakeholders (including competitors) (Camilleri, 2019) to benefit from synergistic resources and capabilities, to increase their economies of scale and scope, to thrive in an increasingly competitive environment.

Currently, many businesses are still feeling the impact of the Coronavirus (COVID-19) pandemic (Albattat et al., 2020; Camilleri, 2021b; Chemli et al., 2020; Toanoglou et al., 2021). During this crisis, family enterprises and other companies, faced serious liquidity shortages and became cash strapped after they experienced a considerable decline in their business activities. In many cases, they were resilient as they reinforced their purpose and values to ensure that their business remains intact. Generally, they strived in their endeavors to safeguard their financial and emotional investments, to preserve their legacy. Those family owner managers that have better adapted to the pandemic and who are still operating their tourism or hospitality business are better prepared for economic growth and development in the post-pandemic context. 


\section{Limitations}

The contribution is not without limitations. Although this systematic review has carefully considered rigorous articles and reviews that are focused on the development of family businesses in tourism and hospitality, there is scope to investigate different forms of family hotels and family restaurants in more depth and breadth, in terms of their sizes, types of ownership, succession issues, organizational cultures, access to financial resources, et cetera. Future studies can explore the differences between family enterprises and SMEs within the tourism and hospitality industries, in various contexts.

\section{Acknowledgements}

The authors thank the anonymous reviewers for their constructive remarks and suggestions.

\section{References}

Ahmad, S. Z. (2015), "Entrepreneurship in the small and medium-sized hotel sector", Current Issues in Tourism, Vol. 18, No. 4, pp. 328-349.

Ahmad, S. Z., and Muhammad Arif, A. M. (2016), "Entrepreneurial characteristics, motives, and business challenges: exploratory study of small-and medium-sized hotel businesses", International Journal of Hospitality and Tourism Administration, Vol. 17, No. 3, pp. 286-315.

Albattat, A., Jamaludin, A., Zuraimi, N.S.M. and Valeri, M. (2020), "Visit Intention and Destination Image in Post- Covid- 19 Crisis Recovery", Current Issues in Tourism, 24(17), pp. 2392-2397. DOI: https://doi.org/10.1080/13683500.2020.1842342

Andersson, T., Carlsen, J., and Getz, D. (2002), "Family business goals in the tourism and hospitality sector: Case studies and cross-case analysis from Australia, Canada, and Sweden", Family Business Review, Vol. 15, No. 2, pp. 89-106.

Arcese, G., Valeri, M., Poponi, S. and Elmo, G. C. (2020), "Innovative drivers for family business models in tourism", Journal of Family Business Management, Vol. 11, No. 4, pp. 402-422.

Astrachan, J. H., and Shanker, M. C. (2003), Family businesses' contribution to the US economy: A closer look", Family Business Review, Vol. 16, No. 3, pp. 211-219.

Astrachan, J. H., Klein, S. B., and Smyrnios, K. X. (2002), "The F-PEC scale of family influence: A proposal for solving the family business definition problem", Family Business Review, Vol. 15, No. 1, pp. 45-58.

Baggio, R. and Valeri, M. (2020), "Network science and sustainable performance of family businesses in tourism", Journal of Family Business Management. https://doi.org/10.1108/JFBM-06-2020-0048

Brune, A., Thomsen, M. and Watrin, C. (2019), "Family firm heterogeneity and tax avoidance: The role of the founder", Family Business Review, Vol. 32, No. 3, pp. 296-317. 
Bujan, I. (2020), "Entrepreneurial orientation and socioemotional dimensions in small family hotels: do they impact business performance?", Economic Research-Ekonomska istraživanja, Vol. 33, No. 1, pp. 1925-1942.

Camilleri, M. (2014). Advancing the sustainable tourism agenda through strategic CSR perspectives. Tourism Planning \& Development, Vol. $11 . \quad$ No. 1, pp. 42-56. https://www.tandfonline.com/doi/abs/10.1080/21568316.2013.839470

Camilleri, M. A. (2016). Responsible tourism that creates shared value among stakeholders. Tourism Planning \& Development, Vol. 13, No. 2, pp. 219-235. https://www.tandfonline.com/doi/abs/10.1080/21568316.2015.1074100

Camilleri, M. A. (2017). Corporate sustainability and responsibility: creating value for business, society and the environment. Asian Journal of Sustainability and Social Responsibility, Vol. 2, No. 1, pp. 59-74. https://ajssr.springeropen.com/articles/10.1186/s41180-017-0016-5

Camilleri, M.A. (2018). Nurturing travel and tourism enterprises for economic growth and competitiveness. Tourism and Hospitality Research, Vol. 18, No. 1, pp. 123-127. https://journals.sagepub.com/doi/abs/10.1177/1467358415621947

Camilleri, M.A. (2019), "The SMEs' technology acceptance of digital media for stakeholder engagement", Journal of Small Business and Enterprise Development, Vol. 26 No. 4, pp. 504-521. https://doi.org/10.1108/JSBED-02-2018-0042

Camilleri, M. A. (2020). Strategic corporate social responsibility in tourism and hospitality. Strategic Corporate Social Responsibility in Tourism and Hospitality. Sustainable Development, Vol. 28, No. 3, pp.504-506.

Camilleri, M. A. (2021a), "Strategic attributions of corporate social responsibility and environmental management: The business case for doing well by doing good!", Sustainable Development. https://onlinelibrary.wiley.com/doi/abs/10.1002/sd.2256

Camilleri, M. A. (2021b). The Employees' State of Mind during COVID-19: A Self-Determination Theory Perspective. Sustainability, Vol. 13 No. 7, 3634. https://www.mdpi.com/2071$\underline{1050 / 13 / 7 / 3634}$

Camisón, C., Forés, B., and Puig-Denia, A. (2016), "Return on capital in Spanish tourism businesses: A comparative analysis of family vs non-family businesses", European Journal of Management and Business Economics, Vol. 25, No. 3, pp. 91-110.

Canovi, M., and Lyon, A. (2020), "Family-Centred Motivations for Agritourism Diversification: The Case of the Langhe Region, Italy", Tourism Planning \& Development, Vol. 17, No. 6, pp. 591-610.

Chan, J. K. L., and Quah, W. B. (2012), "Start-up factors for small and medium-sized accommodation businesses in Sabah, Malaysia: Push and pull factors", Asia Pacific Journal of Tourism Research, Vol. 17, No. 1, pp. 49-62.

Chemli, S., Toanoglou, M. and Valeri, M. (2020), "The impact of Covid-19 media coverage on tourist's awareness for future traveling", Current Issues in Tourism. DOI 10.1080/13683500.2020.1846502

Chrisman, J. J., Chua, J. H., and Sharma, P. (2005), "Trends and directions in the development of a strategic management theory of the family firm", Entrepreneurship Theory and Practice, Vol. 29, No. 5, pp. 555-575.

Çiçek, D., Zencir, E., and Kozak, N. (2017), "Women in Turkish tourism”, Journal of Hospitality and Tourism Management, Vol. 31, pp. 228-234.

Craig, J., and Lindsay, N. J. (2002), "Incorporating the family dynamic into the entrepreneurship process", Journal of Small Business and Enterprise Development, Vol. 9, No. 4, pp. 416-430.

Elmo, G. C., Arcese, G., Valeri, M., Poponi, S., and Pacchera, F. (2020), "Sustainability in tourism as an innovation driver: An analysis of family business reality", Sustainability, Vol. 12 No. 15, 6149.

Engeset, A. B. (2020), "For better or for worse"-the role of family ownership in the resilience of rural hospitality firms", Scandinavian Journal of Hospitality and Tourism, Vol. 20, No. 1, pp. 68-84.

Erdogan, I., Rondi, E., and De Massis, A. (2020), "Managing the tradition and innovation paradox in family firms: A family imprinting perspective", Entrepreneurship Theory and Practice, Vol. 44, No. 1, pp. 20-54. 
Esparza Aguilar, J.L. (2019), "Corporate social responsibility practices developed by Mexican family and non-family businesses", Journal of Family Business Management, Vol. 9, No. 1, pp. 40-5

Fonseca, A. P., and Carnicelli, S. (2021), "Corporate Social Responsibility and Sustainability in a Hospitality Family Business", Sustainability, Vol. 13, No. 13, 7091.

Fyfe, J., Bent, R., and Seaman, C. (2020), "Business internet use in small, family owned and managed hotels in Scotland", International Journal of Business and Globalisation, Vol. 24, No. 2, pp. 256274.

Getz, D., and Carlsen, J. (2000), "Characteristics and goals of family and owner-operated businesses in the rural tourism and hospitality sectors", Tourism Management, Vol. 21, No. 6, pp. 547-560.

Getz, D., and Carlsen, J. (2005), "Family business in tourism: State of the art", Annals of Tourism Research, Vol. 32, No. 1, pp. 237-258.

Getz, D., Carlsen, J., and Morrison, A. (2004), The family business in tourism and hospitality. CABI, Wallingford, UK.

Giacosa, E., Ferraris, A., and Monge, F. (2017), "How to strengthen the business model of an Italian family food business", British Food Journal, Vol. 119, No. 11, pp.2309-2324.

Glowka, G., and Zehrer, A. (2019), "Tourism family-business owners' risk perception: Its impact on destination development", Sustainability, Vol. 11, No. 24, 6992.

Habbershon, T. G., Williams, M., and MacMillan, I. C. (2003), "A unified systems perspective of family firm performance", Journal of Business Venturing, Vol. 18, No. 4, pp. 451-465.

Hallak, R., and Assaker, G. (2013), "Family vs. non-family business owners' commitment to their town: A multigroup invariance analysis", Asia Pacific Journal of Tourism Research, Vol. 18, No. 6, pp. 618-636.

Hallak, R., Assaker, G., and O'Connor, P. (2014), "Are family and nonfamily tourism businesses different? An examination of the entrepreneurial self-efficacy-entrepreneurial performance relationship", Journal of Hospitality and Tourism Research, Vol. 38, No. 3, pp. 388-413.

Heimerl, P., and Peters, M. (2019), "Shaping the future of Alpine tourism destinations' next generation: an action research approach", Tourism: An International Interdisciplinary Journal, Vol. 67 No. 3, pp. 281-298.

Ismail, H. N., Mohd Puzi, M. A., Banki, M. B., and Yusoff, N. (2019) "Inherent factors of family business and transgenerational influencing tourism business in Malaysian islands", Journal of Tourism and Cultural Change, Vol. 17, No. 5, pp. 624-641.

Jaafar, M., Rashid Abdul Aziz, A., and Zaleha Mohd Sukarno, S. (2012), "Tourism marketing: An overview of small and medium budget hotels (SMBHs)", Asia Pacific Journal of Tourism Research, Vol. 17, No. 1, pp. 1-13.

Kallmuenzer, A. (2018), "Exploring drivers of innovation in hospitality family firms", International Journal of Contemporary Hospitality Management, Vol. 30 No. 3, pp. 1978-1995.

Kallmuenzer, A., and Peters, M. (2018), "Innovativeness and control mechanisms in tourism and hospitality family firms: A comparative study", International Journal of Hospitality Management, Vol. 70, pp. 66-74.

Kallmuenzer, A., Nikolakis, W., Peters, M., and Zanon, J. (2018), “Trade-offs between dimensions of sustainability: Exploratory evidence from family firms in rural tourism regions", Journal of Sustainable Tourism, Vol. 26, No. 7, pp. 1204-1221.

Kumar, S., Valeri, M. and Shekhar (2021), "Understanding the relationship among factors influencing rural tourism: A hierarchical approach", Journal of Organizational Change Management. DOI 10.1108/JOCM-01-2021-0006

Lee, Y. S., and Shin, W. J. (2015), "Marketing tradition-bound products through storytelling: a case study of a Japanese sake brewery", Service Business, Vol. 9, No. 2, pp. 281-295.

López-Chávez, B. A., Maldonado-Alcudia, C., and Larrañaga Núñez, A. M. (2020), "Family business in tourism: an international systematic review of literature with an emphasis on Latin America" Academia Revista Latinoamericana de Administración, Vol. ahead-ofprint No. ahead-of-print. https://doi.org/10.1108/ARLA-06-2020-0140 
Martínez, J. I., Stöhr, B. S., and Quiroga, B. F. (2007), “ Family ownership and firm performance: Evidence from public companies in Chile" Family Business Review, Vol. 20 No. 2, pp. 83-94.

Miller, D., Steier, L., and Le Breton-Miller, I. (2003), "Lost in time: Intergenerational succession, change, and failure in family business", Journal of Business Venturing, Vol. 18 No. 4, pp. 513-531.

Moher, D., Shamseer, L., Clarke, M., Ghersi, D., Liberati, A., Petticrew, M., ... and Stewart, L. A. (2015). "Preferred reporting items for systematic review and meta-analysis protocols (PRISMA-P) 2015 statement", Systematic Reviews, Vol. 4, No. 1, pp. 1-9.

Morrison, A. (2006), "A contextualisation of entrepreneurship", International Journal of Entrepreneurial Behavior and Research, Vol. 12, No. 4, pp. 192-209.

Mtapuri, O., Camilleri, M.A. and Dłużewska, A. (2021), "Advancing community-based tourism approaches for the sustainable development of destinations:", Sustainable Development. https://onlinelibrary.wiley.com/doi/abs/10.1002/sd.2257

Nguyen, H. T., Costanzo, L. A., and Karatas-Özkan, M. (2020), "Stakeholders' perceptions of sustainable entrepreneurship within the context of a developing economy", Journal of Small Business Management, 1-40.

Obermayer, N., Kővári, E., Leinonen, J., Bak, G. and Valeri, M. (2021), "How social media practices shape family business performance: the wine industry case study", European Management Journal. DOI: 10.1016/j.emj.2021.08.003

OECD (2021). OECD Corporate Governance Factbook 2021, Organization for Economic Cooperation and Development, Paris, France. https://www.oecd.org/corporate/corporategovernancefactbook.htm

Ollenburg, C., and Buckley, R. (2011), Which farmers turn to tourism? A continental-scale analysis. Tourism Recreation Research, Vol. 36, No. 2, pp. 127-140.

Peña-Miranda, D.D., Guevara-Plaza, A., Fraiz-Brea, J.A. and Camilleri, M.A. (2021), "Corporate social responsibility model for a competitive and resilient hospitality industry", Sustainable Development. https://onlinelibrary.wiley.com/doi/abs/10.1002/sd.2259

Peters, M., and Buhalis, D. (2004), "Family hotel businesses: strategic planning and the need for education and training", Education+ Training, Vol. 46, No. 8-9, 406-415.

Peters, M., and Kallmuenzer, A. (2018), "Entrepreneurial orientation in family firms: The case of the hospitality industry", Current Issues in Tourism, Vol. 21, No. 1, 21-40.

Peters, M., Raich, M., Märk, S. and Pichler, S. (2012), "The role of commitment in the succession of hospitality businesses", Tourism Review, Vol. 67, No. 2, pp. 45-60.

Pikkemaat, B., and Zehrer, A. (2016), "Innovation and service experiences in small tourism family firms", International Journal of Culture, Tourism and Hospitality Research. Vol. 10 No. 4, pp. 343360.

Presas, P., Guia, J., and Muñoz, D. (2014), "Customer's perception of familiness in travel experiences", Journal of Travel and Tourism Marketing, Vol. 31, No. 2, pp. 147-161.

Presas, P., Muñoz, D., and Guia, J. (2011), "Branding familiness in tourism family firms", Journal of Brand Management, Vol. 18, No. 4, pp. 274-284.

Prevolšek, B., Rozman, Č., Pažek, K., Maksimović, A., and Potočnik Topler, J. (2017). "Development of family tourism businesses in rural areas: Multi criteria assessment of businesses in easter Slovenia", Podravina: časopis za multidisciplinarna istraživanja, Vol. 16, No. 32, pp 136-149.

Rachmawati, E., Suliyanto and Suroso, A. (2020), "Direct and indirect effect of entrepreneurial orientation, family involvement and gender on family business performance", Journal of Family Business Management, Vol. ahead-of-print No. ahead-of-print. https://doi.org/10.1108/JFBM-072020-0064

Russo, A. and Tencati, A. (2009), "Formal vs. informal CSR strategies: Evidence from Italian micro, small, medium-sized, and large firms", Journal of Business Ethics, Vol. 85 No. 2, pp. 339-353.

Santos, V., Ramos, P., Sousa, B., Almeida, N. and Valeri, M. (2021a), "Factors influencing touristic consumer behavior", Journal of Organizational Change Management. DOI: 10.1108/JOCM-022021-0032 
Santos, V., Ramos, P., Sousa, B. and Valeri, M. (2021c), "Towards a framework for the global wine tourism system", Journal of Organizational Change Management, https://doi.org/10.1108/JOCM11-2020-0362

Santos, V., Sousa, B., Ramos, P. and Valeri, M. (2021b), "Emotions and Involvement in Tourism Settings", Current Issues in Tourism. DOI: 10.1080/13683500.2021.1932769

Seaman, C., McQuaid, R. and Pearson, M. (2017), "Social networking in family businesses in a local economy", Local Economy, Vol. 32 No. 5, pp. 451-466.

Shaw, G., and Williams, A. M. (2013). From lifestyle consumption to lifestyle production: Changing patterns of tourism entrepreneurship. In Small Firms in Tourism (pp. 109-124). Routledge, Oxford, UK.

Steier, L. (2001), "Next-generation entrepreneurs and succession: An exploratory study of modes and means of managing social capital", Family Business Review, Vol. 14, No. 3, pp. 259-276.

Steier, L. (2003), "Variants of agency contracts in family-financed ventures as a continuum of familial altruistic and market rationalities", Journal of Business Venturing, Vol. 18 No. 5, pp. 597-618.

Toanoglou, M., Chemli, S. and Valeri, M. (2021), "The organizational impact of COVID-19 crisis on travel perceived risk across four continents", Journal of Organizational Change Management. DOI 10.1108/JOCM-12-2020-0369

Troise, C., \& Camilleri, M. A. (2021). The use of digital media for marketing, CSR communication and stakeholder engagement. In Strategic corporate communication in the digital age. Emerald Publishing Limitedm Bingley, UK.

Valeri, M. (2016), "Networking and cooperation practices in the Italian tourism business", Journal of Tourism, Heritage \& Services Marketing, Vol. 2, No. 1, pp. 30-35. DOI: http://doi.org/10.5281/zenodo.376333

Valeri, M. (2021), Organizational Studies. Implications for the Strategic Management, Springer

Valeri, M. and Baggio, R. (2020a), "Social network analysis: organizational implications in tourism management", International Journal of Organizational Analysis, Vol. 29, No. 2, pp. 342-353. DOI: 10.1108/IJOA-12-2019-1971

Valeri, M. and Baggio, R. (2020b), "Italian tourism intermediaries: a social network analysis exploration", Current Issues in Tourism, Vol. 24, No. 9, pp. 1270-1283. DOI: https://doi.org/10.1080/13683500.2020.1777950

Valeri, M. and Baggio, R. (2020c), "A critical reflection on the adoption of blockchain in tourism", Journal Information Technology and Tourism, Vol. 23, No. 2, pp. 121-132. DOI: 10.1007/s40558020-00183-1

Valeri, M. and Baggio, R. (2021), "Increasing the efficiency of knowledge transfer in an Italian tourism system: a network approach", Current Issues in Tourism. DOI: 10.1080/13683500.2021.1937960

Valeri M. and Katsoni V. (Eds.) (2021), Gender and tourism: challenges and entrepreneurial opportunities, Emerald Publishing

Veloso, C. M., Walter, C. E., Sousa; B., Olivera, M., Valeri, M. (2021), “Academic tourism and transport services: student perceptions from a social responsibility perspective", Sustainability. DOI: https://doi.org/10.3390/su13168794

Vrontis, D., Bresciani, S., and Giacosa, E. (2016), "Tradition and innovation in Italian wine family businesses", British Food Journal, Vol. 118 No. 8, pp. 1883-1897.

Vrontis, D., Culasso, F., Giacosa, E. and Stupino, M. (2019), "Entrepreneurial exploration and exploitation processes of family businesses in the food sector", British Food Journal, Vol. 121 No. 11, pp. 2759-2779.

Walton, J. K. (2014), "Family firm, health resort and industrial colony: The grand hotel and mineral springs at Mondariz Balneario, Spain, 1873-1932”, Business History, Vol. 56, No. 7, pp. 1037-1056.

Williams Jr, R. I., Pieper, T. M., Kellermanns, F. W., and Astrachan, J. H. (2018), "Family firm goals and their effects on strategy, family and organization behavior: A review and research agenda", International Journal of Management Reviews, Vol. 20, pp. S63-S82. 